\title{
Evaluation of Bacterial Strains for the Induction of Plant Biochemicals, Nutritional Contents and Isozymes in Barley
}

\author{
Anam Yousaf', Abdul Qadir ${ }^{2}$, Tehmina Anjum ${ }^{3}$, Dr Rizwan Ishaq Khan ${ }^{4}$, Declan Naughton ${ }^{5}$ and Ali Yousaf \\ ${ }^{1}$ College of Earth and Environmental Sciences, University of the Punjab, Lahore, Pakistan \\ ${ }^{2}$ College of Earth and Environmental Sciences, Lahore, Pakistan \\ ${ }^{3}$ Institute of Agricultural Sciences, Banaras Hindu University, Varanasi, Uttar Pradesh \\ ${ }^{4}$ Cavan General Hospital, Ireland \\ ${ }^{5}$ Kingston University, London \\ ${ }^{6}$ University of Management and Technology, Lahore
}

\begin{abstract}
Acetobacter aceti was successfully used to induce transcriptional analysis, plant biochemical profile and nutritional contents in barley. Association of barley and microbial strain AC8 was reported best combination among other eight microbial strains of Bacillus in this study. AC8 microbial strain was identified as $A$. aceti from Fungal Culture Bank, Institute of Agricultural Science, University of the Punjab, Lahore, Pakistan. Different strains of $A$. aceti i.e., AC1, AC2, AC3... AC8 were analyzed as plant inducers and AC8 was screened out as best inducer in barley. It induced highest quantities of plant biochemical (i.e., phytosterols, phenolics, alkaloids and terpenoids) in barley. Current study revealed that among eight microbial strains AC8 had maximum potential to increase ascorbic acid, panthothenic acid, pyridoxine, thiamine and riboflavin in barley than other microbial strains. AC8 screened out among other microbial strains on the basis of its high vitamins induction potential. AC3 plus AC6 were reported second in the recorded list although other strains had a chronological reduction in vitamins as AC2>AC7>AC4>AC5 and AC1. Further evaluation of AC8 was done to check its efficiency for biochemicals, nutritional and isozyme contents induction in barley. Statistical analysis was performed using ANOVA and DMRT through DSAASTAT.
\end{abstract}

Keywords: Fungal Culture bank Pakistan (FCBP); Acetobacter aceti; Oxidoaqualene Cyclase (OSC); Plant Growth Promoting Rhizobacteria (PGPR)

\section{Introduction}

Plant and microbes have a distinctive relationship among them from last decade. Worldwide plants including major crops facing serious threat due to biotic and abiotic stresses [1]. To minimize these challenges plants and microbes sometimes build a mutual relationship between them to benefit each other. However, very rarely it has seen that microbes use plants as host to invade them for their life cycle completion and parallel plants eat microbes identified as intruder as reported in recent study by Paungfoo-Lonhienne et al. [2]. In most of the cases plants and microbes develop symbiotic relationship where they do not cause pathogenicity to each other and develop bilateral combination to benefit each other as a host medium. Microbes and plants develop coordination and suppress the pathogenicity of certain host by limiting the infection [3].

Now a day Plant Growth Promoting Rhizobacteria (PGPR) used widely in research to promote the plant microbe interaction without causing pathogenicity [4]. Because these are naturally occurring microbes mostly found in soil and water to make a mutual relationship with plants and induce their nutritional contents and growth promoting factors [5]. Such PGPR act as a barrier against small microorganism deleterious effects and protect the plant silently from its growth suppression. There are multiple ways through which these microbes enhance plant growth and ecologically modulate plant nutritional profile [6]. The certain ways are nutrients solublization such as $\mathrm{P}$ [7], nitrogen fixation [8], regulation of ethylene in roots [9], enhancing mycorrhizal function [10], phytohormones secretion [11,12], nutrilizing heavy metals absorption [13]. However, it is important to note that these microbes have active metabolites which eliminate the deleterious effect of small disease causing pathogens plus promote plant growth and increase its nutritional contents [14]. PGPR acts on plant roots to eliminate toxic compounds and promote plant growth [15].
Microbial inducer was used to induce plant biochemicals, nutritional contents and isozymes profile in this study. Induction of plant biochemicals and nutritional contents were induced with the help of microbial strain. The microbial strains of Bacillus obtained from the soil of Institute of Agricultural Science, University of the Punjab, Lahore, Pakistan. Further bacterial strains were used in this study to evaluate the best plant microbial interaction which has maximum affinity with barley and induced high levels of nutritional and biochemical profile. Total eight microbial strains were selected i.e., (AC1, AC2, AC3, AC4, $\mathrm{AC} 5, \mathrm{AC} 6, \mathrm{AC} 7$ and $\mathrm{AC} 8$ ) on the basis of their contribution towards the plant growth and enhanced nutritional contents.

\section{Methodology}

\section{Procurement of Bacterial strains and Barley seeds}

Different Bacillus strains (i.e., AC1, AC2, AC3..... AC8) were used and selected staple food crop i.e., barley (Zarghoon VI) was grown in semi controlled greenhouse conditions of "Institute of Agricultural Sciences, University of the Punjab Lahore, Pakistan" at $22 \pm 2^{\circ} \mathrm{C}$. Barley was treated with different microbial strains (i.e., AC1, AC2, AC3.... AC8). Seeds were harvested and collected for further studies. Seeds were grown under semi controlled environmental factors to enhance inducers ability to induce phytosterols content. Seeds were physically

*Corresponding author: Yousaf A, College of Earth and Environmental Sciences, University of the Punjab, Lahore, Pakistan, Tel: +4407848276881; E-mail anamyousaf34@gmail.com

Received July 20, 2017; Accepted August 03, 2017; Published August 10, 2017

Citation: Yousaf A, Qadir A, Anjum T, Khan RI, Naughton D, et al. (2017) Evaluation of Bacterial Strains for the Induction of Plant Biochemicals, Nutritional Contents and Isozymes in Barley. J Nutr Food Sci 7: 623. doi: 10.4172/2155-9600.1000623

Copyright: () 2017 Yousaf A, et al. This is an open-access article distributed under the terms of the Creative Commons Attribution License, which permits unrestricted use, distribution, and reproduction in any medium, provided the original author and source are credited. 
examined to confirm their clear and mature size. Seeds were collected from the selected staple food crop barley which screened out as best phytosterols producing crop among other native cultivated staple food crops.

\section{Preparation of inoculum}

Inoculum of each microbial strain was separately prepared from $16 \mathrm{~h}$ old microbial cultures. Microbial cells were collected through centrifugation at $5000 \mathrm{rpm}$ and then its inoculum was prepared in distilled sterilized water. Inoculum concentration of each microbial strain was adjusted to $1 \times 10^{6}$ microbial cells $/ \mathrm{mL}$ by using haemocytometer.

\section{Pot experiment}

One hundred $\mathrm{mL}$ of microbial inoculum was added into soil of respective pots, containing three barley plants in each pot. Each treatment was replicated thrice, while each replicate was consisted of 32 pots. Plants were watered when needed and seeds of mature plants were randomly harvested prior to their processing for biochemical, nutritional and isozyme analysis. Barley plants were exposed to eight different bacterial strains and later on checked their association with the best bacterial inducer strain. When plants were matured their seeds were harvested and tested against plant biochemicals, nutritional contents and isozyme analysis.

\section{Analysis of palatability related biochemicals}

Palatability related biochemicals were assessed by "Double beam UV-Vis spectrophotometer-Shimadzu-1800, equipped with $1 \mathrm{~cm}$ quartz cell and dry mass suspension methods (Maynard, 1970). Results were recorded and analyzed using ANOVA and Duncan's Multiple Range Test (DMRT).

\section{Phytosterols}

Phytosterols mass was quantified by dry suspension method [16]. One gram of preweighed crushed seeds were taken and extracted with $80 \%$ ethanol. Mixture was left at room temperature for $30 \mathrm{~min}$ and filtered. Filterate was transferred in to a new preweighed petri plate. Next step was the addition of $5 \mathrm{~mL}$ of $1 \% \mathrm{NaOH}$ in it and mixed well before the addition of $5 \mathrm{~mL}$ of $\mathrm{n}$-Hexane. Filtrate was again mixed and let it dry for $24 \mathrm{~h}$ in hot air oven to obtain thick mass of phytosterols and weighed again. The final concentration of phytosterols was obtained through dry weight through this formula $\mathrm{W}_{2}-\mathrm{W}_{1}[17]$.

\section{Coumarins}

Coumarin contents were measured using spectrophotometer. Five grams seeds were crushed and $0.5 \mathrm{~mL}$ of extract was added into a test tube. Before carrying the dilution of extract with $9 \mathrm{~mL}$ of distilled water, added $9 \mathrm{~mL}$ of $5 \%$ lead acetate into it and mixed well. Two $\mathrm{mL}$ of this mixture was transferred to a new test tube. In the same tube $8 \mathrm{~mL}$ of $0.1 \mathrm{M} \mathrm{HCl}$ solution was added and left the test tube at room temperature for $30 \mathrm{~min}$. Absorbance was taken at this wavelength 320 $\mathrm{nm}$ which was then used to calculate the quantity of coumarins with the help of standard curve made by using different concentration of lead acetate [18].

\section{Tannins}

Tannin content was quantified by spectrophotometer. Preweighed five grams of crushed samples were taken in $100 \mathrm{~mL}$ of volumetric flask and filled with $50 \mathrm{~mL}$ of distilled water. Mixture was shaken well and filtered. $5 \mathrm{~mL}$ of the filterate was transferred into another flask and added $3 \mathrm{~mL}$ of $0.1 \mathrm{M}$ Feric Chloride $\left(\mathrm{FeCl}_{3}\right)$ with $0.1 \mathrm{M}(\mathrm{HCl})$ and $0.008 \mathrm{M}$ potassium ferrocyanide. The absorbance was measured at $760 \mathrm{~nm}$. A blank sample was prepared and calculated at the same wavelength. A standard was prepared using tannin acid to achieve 100 ppm concentration to quantify tannins [19].

\section{Flavonoids}

Quantification of flavonoids was measured by taking $0.5 \mathrm{~mL}$ of sample extracts into a test tube. Then, $0.5 \mathrm{~mL}$ of $10 \%$ acetic acid solution was added into it and mixed well. Then, $2 \mathrm{~mL}$ of $5 \%$ pyridine solution was added with $1 \mathrm{~mL}$ of $5 \%$ aluminum chloride solution and $6 \mathrm{~mL}$ of $80 \%$ methanol. The mixture was then incubated at room temperature for $30 \mathrm{~min}$ and filtered through whatman filter paper number 42 thrice. The filterate was then transferred into a petri plate and evaporated to dryness on a hot plate and weighed [20].

\section{Phenolics}

Five grams of seeds were crushed and extracted with $80 \%$ of methanol at hot plate with constant temperature at $70^{\circ} \mathrm{C}$ for $15 \mathrm{~min}$ to obtain fat free sample. After $15 \mathrm{~min}$ the extract was filtered through filter paper to remove impurities and $1 \mathrm{~mL}$ of extract was transferred into a new glass test tube. Then, $5 \mathrm{~mL}$ of distilled water was added with $0.25 \mathrm{~mL}$ of $10 \%$ folin ciocalteau reagent. Then added $1 \mathrm{~mL}$ of $7.5 \%$ sodium carbonate. Mixture was incubated at $25^{\circ} \mathrm{C}$ for $30 \mathrm{~min}$ to develop colour. Then absorbance was recorded at $725 \mathrm{~nm}$ which was then used to calculate the quantity of phenolics with the help of standard curve made by using different concentration of gallic acid [21].

\section{Alkaloids}

Five grams of crushed seeds were soaked into $20 \%$ of acetic acid solution which was prepared in ethanol. The mixture was incubated for $4 \mathrm{~h}$ at room temperature. Then mixture was filtered through filter paper to remove excess plant material. To determine alkaloid contents the reaction mixture was rotary evaporated to make it one fourth of its original volume. Later on concentrated ammonium hydroxide solution was added to precipitate alkaloids. The entire solution was allowed to stand and the precipitate was collected by filteration, after which it was left for $24 \mathrm{~h}$ and weighed with the help of dry mass [22].

\section{Saponins}

Five gram of crushed seeds were taken and mixed in $100 \mathrm{~mL}$ of $20 \%$ ethanol. The mixture was heated for $4 \mathrm{~h}$ at $55^{\circ} \mathrm{C}$. After, the heating process the extract was filtered through filtration process and divided into equal volumes with the further addition of ethanol. Extracts were incubated for $15 \mathrm{~min}$, combined and evaporated to reduce the total volume up to $40 \mathrm{~mL}$. Half volume was filled with diethyl ether up to $50 \mathrm{~mL}$ and given a vigorous shaking to obtain an aqueous layer. The same step was followed for another half of the filterate with n-butanol. Mixture was shaken well to obtain n-butanol layer. Remove the supernant and given a washing with $5 \% \mathrm{NaCl}(10 \mathrm{~mL})$ and then dried in hot air oven for $24 \mathrm{~h}$ to a constant weight. Saponin content was calculated with dry mass weight [22].

\section{Pectins}

Preweighed $5 \mathrm{~g}$ of crushed seeds were mixed with distilled water at boiling temperature for $1 \mathrm{~h}$ to obtain seed extract. The extract was filtered to remove plant material and obtained clear extract. One $\mathrm{mL}$ of $5 \% \mathrm{NaOH}$ solution and $30 \mathrm{~mL}$ of distilled water was added to this mixture and allowed to incubate for $24 \mathrm{~h}$. Then $5 \mathrm{~mL}$ of $10 \%$ acetic acid solution was added into this mixture and left it overnight. After, $24 \mathrm{~h}$ 
Citation: Yousaf A, Qadir A, Anjum T, Khan RI, Naughton D, et al. (2017) Evaluation of Bacterial Strains for the Induction of Plant Biochemicals, Nutritional Contents and Isozymes in Barley. J Nutr Food Sci 7: 623. doi: 10.4172/2155-9600.1000623

Page 3 of 12

incubation $2.5 \mathrm{~mL}$ of $1 \mathrm{~N}$ calcium chloride was added to obtain visible residues of pectins. The residues were transferred to the previously weighed petri plate. The petri plate along with the residue was placed on a water bath and dried in the oven at $100^{\circ} \mathrm{C}$ until a constant weight was obtained [23].

\section{Terpenoids}

Terpenoids were quantified using one gram of preweighed crushed seeds which were soaked in $10 \mathrm{~mL}$ of heptane. Then the mixture was mixed well and extracted with the addition of water. After, the addition of water an organic visible layer was appeared and separated for terpenoids quantification. Absorbance was recorded at $190 \mathrm{~nm}$ which was then used to calculate the quantity of terpenoids with the help of standard curve made by using variable concentration of heptane [24].

\section{Nutritional analysis}

Nutritional importance of staple food crops were determined by evaluating the vitamin contents. The nutritionally important vitamins includes vitamin $B_{3}$ which is also known as niacin, vitamin $B_{6}$ as pyridoxine, vitamin $B_{5}$ as panthothenic acid, vitamin $B_{1}$ as thiamine, vitamin $B_{2}$ as riboflavin, vitamin $B_{9}$ as folic acid and vitamin $\mathrm{C}$ as ascorbic acid were evaluated by "Double beam UV-Vis spectrophotometer-Shimadzu-1800, equipped with $1 \mathrm{~cm}$ quartz cell. Selected vitamins standards were purchased from Sigma Aldrich. Statistical data was obtained and measured through Duncan's multiple range test (DMRT), ANOVA, DSAASTAT [25].

\section{Niacin (Vitamin $\mathrm{B}_{3}$ )}

Niacin was detected using spectrophotometer. For this purpose 5 $\mathrm{g}$ of crushed samples were mixed in $50 \mathrm{~mL}$ of $1 \mathrm{~N} \mathrm{H}_{2} \mathrm{SO}_{4}$. The mixture was left for $30 \mathrm{~min}$ at room temperature. Then, added 3 drops of $10 \%$ ammonia solution in the mixture slowly. The mixture was allowed to stay for another $15 \mathrm{~min}$. Reaction mixture was filtered and then transferred $10 \mathrm{~mL}$ of the filterate into $50 \mathrm{~mL}$ flask and added $5 \mathrm{~mL}$ of $0.1 \mathrm{M}$ potassium cyanide which further acidified with $0.02 \mathrm{~N} \mathrm{H}_{2} \mathrm{SO}_{4}$ Mixed well and absorbance was taken at $470 \mathrm{~nm}$ which was then used to calculate the quantity of niacin with the help of standard curve made by using different concentration of niacin standard [25].

\section{Pyridoxine (Vitamin B6)}

One gram of each sample was taken into $100 \mathrm{~mL}$ of volumetric flask and added $0.1 \mathrm{~N} \mathrm{HCl}$ upto $50 \mathrm{~mL}$. The reaction mixture was sonicated for $30 \mathrm{~min}$, filtered and then again diluted with $0.1 \mathrm{~N} \mathrm{HCl}$ to attain required pyridoxine concentration. Absorbance was measured at 290 $\mathrm{nm}$ which was further used to calculate the pyridoxine quantification with the help of standard curve made by using different concentrations of $\mathrm{HCl}$ [26].

\section{Panthothenic acid (vitamin B5)}

Five gram of crushed sample was transferred into $50 \mathrm{~mL}$ of volumetric flask and extracted with $0.05 \%$ phosphoric acid up to 50 $\mathrm{mL}$. Mix it well at hot water bath for $30 \mathrm{~min}$. Filter the solution. As pantothenic acid exhibits colorless solution and do not exhibit strong UV absorption above $240 \mathrm{~nm}$. That is why absorbance was measured at low wavelength $190 \mathrm{~nm}$ for detection to obtain an adequate amount of panthothenic acid contents with the comparison against different concentration of phosphoric acid [27].

\section{Thiamine (vitamin B1)}

To determine thiamine five grams of each sample was transferred into $100 \mathrm{~mL}$ volumetric flask with $50 \mathrm{~mL}$ of $80 \%$ ethanol solution. The mixture was filtered and transferred $10 \mathrm{~mL}$ of the filtrate into another flask. Then, added $100 \mu \mathrm{g} \cdot \mathrm{ml}^{-1}$ of $\mathrm{HCl}$ with $10 \mathrm{~mL}$ of $0.1 \mathrm{M}$ (potassium dichromate) $\mathrm{K}_{3}\left[\mathrm{Fe}(\mathrm{CN})_{6}\right]$ and filled distilled water upto the mark. Mixture was sonicated for $20 \mathrm{~min}$. Absorbance was taken at $747 \mathrm{~nm}$ and compared with the standard curve of potassium dichromate [28].

\section{Riboflavin (vitamin B2)}

Quantification of riboflavin was done by taking five grams of each staple food crop sample into $100 \mathrm{~mL}$ of volumetric flask and added 100 $\mathrm{mL}$ of $50 \%$ ethanol. The mixture was sonicated for $1 \mathrm{hr}$ to completely extract the sample. Mixture was filtered and $10 \mathrm{~mL}$ of extract transferred into $50 \mathrm{~mL}$ volumetric flask. Then, added $10 \mathrm{~mL}$ of $5 \%$ potassium permanganate with $10 \mathrm{~mL}$ of $30 \% \mathrm{H}_{2} \mathrm{O}_{2}$. Mixture was sonicated for another $30 \mathrm{~min}$. Then added $2 \mathrm{~mL}$ of $40 \%$ sodium sulphate to achieve $50 \mathrm{~mL}$ volume. Mixture was left for $15 \mathrm{~min}$ at room temperature to get the absorbance at $510 \mathrm{~nm}$ against different concentration of potassium permanganate [25].

\section{Folic acid (vitamin B9)}

Folic acid detection was carried out by taking five grams of each selected staple food crop sample was added into $25 \mathrm{~mL}$ volumetric flask and added three $\mathrm{mL}$ of $3 \%$ phosphate buffer solution of $\mathrm{PH}$ 9.0. It was mixed well, left for $2 \mathrm{hrs}$ and then $10 \mathrm{~mL}$ of ethanol was added to the mixture. Absorbance was taken at $282 \mathrm{~nm}$ which was then used to calculate the quantity of folic acid with the help of standard curve made by using different concentration of ethanol [29].

\section{Ascorbic acid (vitamin C)}

$5 \mathrm{~g}$ of each staple food crop sample was taken into a $25 \mathrm{~mL}$ conical flask. Then added $10 \mathrm{~mL}$ of $0.05 \mathrm{M}$ oxalic acid, $0.02 \mathrm{M}$ EDTA solution into the sample and allowed the mixture to stand overnight to achieve required reaction time. Samples were filtered and $2.5 \mathrm{~mL}$ of each sample mixture was transferred into another $25 \mathrm{~mL}$ brown volumetric flask. Then added $2.5 \mathrm{~mL}$ of $0.05 \mathrm{M}$ oxalic acid and $0.02 \mathrm{M}$ EDTA of the same concentration followed by $0.5 \mathrm{~mL}$ meta-phosphoric acid with $10 \%$ acetic acid, $1 \mathrm{~mL}$ of $5 \% \mathrm{H}_{2} \mathrm{SO}_{4,} 2 \mathrm{~mL}$ of $10 \%$ ammonium molybdate solution and distilled water that made the volume up to $25 \mathrm{~mL}$. Mixture left for $10 \mathrm{~min}$ at room temperature and absorbance was taken at $760 \mathrm{~nm}$ with the help of standard curve made by using different concentration of acetic acid [30].

\section{Isozyme analysis}

Isozymes are also known as isoenzymes that exhibits different forms of enzymes in any chemical reaction. Different isozymes recognized with the same reaction end products. Isozymes have different shapes and sizes but their final end products are same due to their similar single reaction substrate outcome. To determine any particular enzymatic activity, polyacrylamide gel is recommended due to its single substrate reaction. Because polyacrylamide gel provides single substrate to run different enzymes at the same time in its natural undisturbed forms intact throughout the process. At the end of polyacrylamide gel process multiple bands appear which shows the number and quality of isozymes.

\section{Total protein estimation}

Total protein estimation was carried out using micro biuret method $[31,32]$ was extracted by taking $1 \mathrm{~g}$ of selected staple food crops. Sample was washed with running tap water for $5 \mathrm{~min}$. One gram of sample was crushed in chilled pestle and mortar for protein extraction. The sample 
Citation: Yousaf A, Qadir A, Anjum T, Khan RI, Naughton D, et al. (2017) Evaluation of Bacterial Strains for the Induction of Plant Biochemicals, Nutritional Contents and Isozymes in Barley. J Nutr Food Sci 7: 623. doi: 10.4172/2155-9600.1000623

was crushed in chilled "Tris $\mathrm{HCl}$ buffer" (appendix 2 a) for 15 min. Mixture was poured into centrifuge vials and centrifuged at $7490 \times \mathrm{g}$ at $-4^{\circ} \mathrm{C}$ for $25 \mathrm{~min}$ to eliminate excess of plant debris. Supernatant was transferred into a new vial along with $1 \mathrm{~mL}$ of $0.7 \mathrm{M}$ urea to dissolve total protein contents completely. The obtained solution was further used as total protein contents in the identification of Oxidosqualene Cyclase (OSC) isozymes.

\section{Oxidosqualene Cyclase (OSC)}

Oxidosqualene cyclase isozymes of selected staple food crops were identified with the help of a method by Mehlem et al., Plant material was extracted with sodium phosphate buffer at $\mathrm{PH}=7.0$. Gel electrophoresis was done in $12 \%$ polyacrylamide gel and $1 \%$ squalene gel in their native states. The gel was incubated at $35^{\circ} \mathrm{C}$ for $24 \mathrm{hrs}$ and then stained with "oil red O" dye for $30 \mathrm{~min}$. After, staining multiple bands were appeared which were analyzed through "GELANALYZER" software (Lazar, Hungary). Statistical analysis was done through "MYSTAT" (Kroeger, Chicago, USA) software to find out the respective OSC bands in different staple food crops (Figure 1).

\section{Results}

\section{Biochemical analysis after bacterial inoculum}

Total eight microbial strains were induced in barley to enhance phytosterol contents. Among eight microbial strains of A. aceti AC8 was screened out as the best inducer in overall results. AC8 significantly ( $\mathrm{p} \leq 0.05)$ produced higher quantities of phytosterols $(0.008 \pm 0.004$ $\mathrm{g} / \mathrm{kg}$ ) in barley when compared to other microbial strains. Treatment AC6 possessed relatively lower quantities $(0.007 \pm 0.004 \mathrm{~g} / \mathrm{kg})$ of phytosterols. AC5 and AC4 were found with equal numerical values of phytosterol i.e., $0.004 \pm 0.0002 \mathrm{~g} / \mathrm{kg}$. AC3, AC2 and AC1 were found responsible to produce lower amounts of phytosterols $(0.0008$ $\pm 0.0000 \mathrm{~g} / \mathrm{kg}$ and $0.009 \pm 0.0003 \mathrm{~g} / \mathrm{kg}$ ). Among eight strains AC8 was screened out as the best inducer which produced maximum amount of phytosterols in barley (Figure $2 \mathrm{H}$ ).

Eight microbial strains have been biochemically tested to detect quantities of tannins. Among eight strains AC8 and AC3 were screened out as the best inducer which produced maximum quantities of tannins in barley. AC8 and AC3 significantly $(\mathrm{p} \leq 0.05)$ produced maximum quantities of $36.56 \pm 2.13 \mathrm{~g} / \mathrm{kg}$ and $34.32 \pm 2.00 \mathrm{~g} / \mathrm{kg}$ tannins respectively. After this $\mathrm{AC} 2$ and $\mathrm{AC} 1$ possessed relatively lower quantities $(29.70 \pm 1.73$ and $26.71 \pm 1.56 \mathrm{~g} / \mathrm{kg})$ of tannins. AC7 and AC4 were produced insignificantly lower amounts of tannins (19.25 \pm 1.12 and $17.76 \pm 1.03 \mathrm{~g} / \mathrm{kg}$ ) than $\mathrm{AC} 2$ and $\mathrm{AC} 1$. AC6 and AC5 showed almost equal quantities of tannins $(16.26 \pm 0.95$ and $13.28 \pm 0.77 \mathrm{~g} / \mathrm{kg})$ in treated plants (Figure 2E).

Barley had the best association with AC8, AC2 and AC3 which produced maximum amount of coumarins with the numerical values of $52.02 \pm 3.04 \mathrm{~g} / \mathrm{kg}, 51.40 \pm 3.00 \mathrm{~g} / \mathrm{kg}$ and $49.77 \pm 2.91 \mathrm{~g} / \mathrm{kg}$. AC1 was second in the coumarin index with $42.22 \pm 2.46 \mathrm{~g} / \mathrm{kg}$. Other strains had same coumarin induction as AC5 (32.02 $\pm 1.87 \mathrm{~g} / \mathrm{kg}), \mathrm{AC} 4(31.20$ $\pm 1.82 \mathrm{~g} / \mathrm{kg})$, AC6 $(30.38 \pm 1.77 \mathrm{~g} / \mathrm{kg})$ and AC7 $(28.55 \pm 1.67 \mathrm{~g} / \mathrm{kg})$ respectively. Among eight microbial strains AC8, AC2 and AC3 showed the maximum potential to induce coumarins in barley. Increased amount of coumarins was related to sweet taste of barley (Figure 2G).

AC1 most significantly $(\mathrm{p} \leq 0.05)$ induced maximum quantities $(0.009 \pm 0.0005 \mathrm{~g} / \mathrm{kg})$ of flavonoids in barley among other tested microbial strains. AC6 was found second in flavonoids index that induced quantities up to $0.007 \pm 0.0004 \mathrm{~g} / \mathrm{kg}$. AC3 and AC4 were found third on flavonoids index with equal numerical values of $0.004 \pm 0.0002$ $\mathrm{g} / \mathrm{kg}$. AC2 was reported after AC3 and AC4 with lesser quantities $(0.0003 \pm 0.0001 \mathrm{~g} / \mathrm{kg})$ of flavonoids which were significantly lower than AC1 and AC6. Strains AC8, AC7 and AC5 were found responsible to produce least amounts of flavonoids $(0.002 \pm 0.0001 \mathrm{~g} / \mathrm{kg})$. Hence, in case of flavonoids induction $\mathrm{AC} 1$ was screened out as the best inducer which produced maximum amount of flavonoids in barley (Figure 2I).

Barley showed maximum association with AC6 which induced maximum amount $(0.009 \pm 0.0005 \mathrm{~g} / \mathrm{kg})$ of alkaloids. AC4 was found second in alkaloids index with the numerical value of $0.008 \pm 0.0004$ $\mathrm{g} / \mathrm{kg}$. AC5 possessed relatively lesser quantities of alkaloids $(0.007 \pm$ $0.0004 \mathrm{~g} / \mathrm{kg}$ ) than AC4. AC2 and AC3 were found next with the same numeric values of $0.004 \pm 0.0002 \mathrm{~g} / \mathrm{kg}$, while AC8 was induced even lesser with $0.003 \pm 0.0001 \mathrm{~g} / \mathrm{kg}$ alkaloids. Other strains AC7 and $\mathrm{AC} 1$ induced alkaloids as $0.002 \pm 0.0001 \mathrm{~g} / \mathrm{kg}$ of the same numeric values, while least alkaloids were induced in AC7 and AC1 among other strains. Barley had the maximum association with AC6 as a best inducer (Figure 2B).

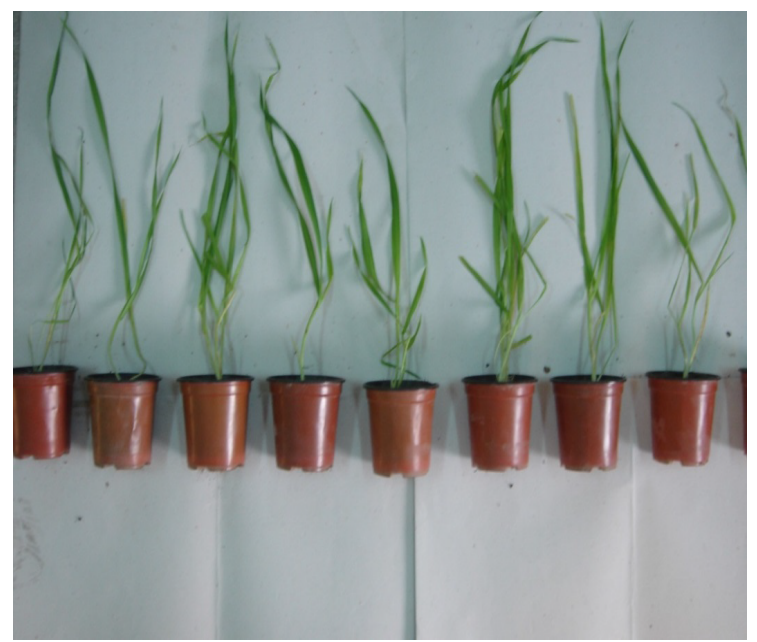

Figure 1: Barley plants grown in pots under greenhouse conditions to evaluate efficacy of bacterial inoculum. 
Citation: Yousaf A, Qadir A, Anjum T, Khan RI, Naughton D, et al. (2017) Evaluation of Bacterial Strains for the Induction of Plant Biochemicals, Nutritional Contents and Isozymes in Barley. J Nutr Food Sci 7: 623. doi: 10.4172/2155-9600.1000623
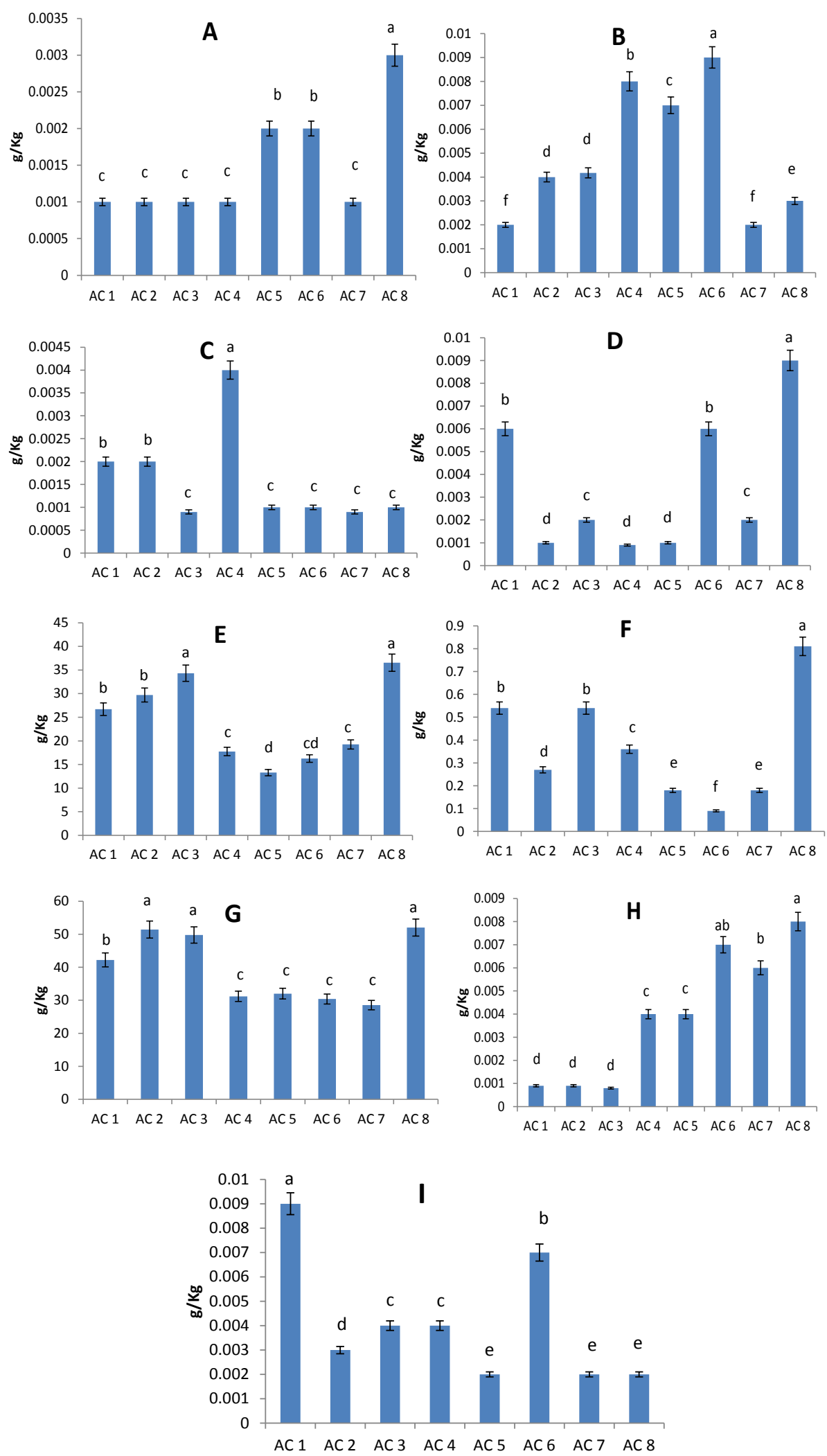

Figure 2: Quantification of different biochemicals in barley after microbial inoculum. Pectins (A), Alkaloids (B), Saponins (C), Phenolics (D), Tannins (E), Terpenoids $(F)$, Coumarins $(G)$, Phytosterols $(\mathrm{H})$ and Flavonoids $(\mathrm{I})$. Data were statistically analysed through DMRT at $p \leq 0.05$ and significance of data was shown by alphabets $(\mathrm{a}, \mathrm{b}, \mathrm{c} . . . \mathrm{f})$. Standard error were calculated through DSAASTAT (Onofri, Italy) and applied in the form of error bars. 
Citation: Yousaf A, Qadir A, Anjum T, Khan RI, Naughton D, et al. (2017) Evaluation of Bacterial Strains for the Induction of Plant Biochemicals, Nutritional Contents and Isozymes in Barley. J Nutr Food Sci 7: 623. doi: 10.4172/2155-9600.1000623

Among eight microbial strains AC8 induced maximum quantities $(0.009 \pm 0.0005 \mathrm{~g} / \mathrm{kg})$ of total phenols in barley. AC1 and AC6 followed this with total phenols of $0.006 \pm 0.0003 \mathrm{~g} / \mathrm{kg}$. AC7 and AC3 were found third on phenol index with a same numeric value of $0.002 \pm 0.0001 \mathrm{~g} / \mathrm{kg}$ which was significantly ( $\mathrm{p} \leq 0.05)$ lesser than AC8, AC1 and AC6 and higher than AC5, AC2 and AC4. Thus, AC5, AC2 and AC4 produced same quantities of phenols $(0.001 \pm 0.0000$ and $0.0009 \pm 0.0000 \mathrm{~g} / \mathrm{kg})$ in barley (Figure 2D).

AC4 induced highest quantities $(0.004 \pm 0.002 \mathrm{~g} / \mathrm{kg})$ of saponins in barley among other eight microbial strains. AC1 and AC2 induced saponin quantities $(0.002 \pm 0.0001 \mathrm{~g} / \mathrm{kg})$ that were second highest among the eight strains. All the other strains including AC3, AC5, AC6, AC7 and AC8 were found statistically ( $\mathrm{p} \leq 0.05)$ similar $(0.001 \pm$ $0.0000 \mathrm{~g} / \mathrm{kg}$ ) for saponin production (Figure $2 \mathrm{C}$ ).

AC8 induced highest quantities $(0.003 \pm 0.0001 \mathrm{~g} / \mathrm{kg})$ of pectin in barley. AC5 and AC6 induced slightly lower quantities of pectin $(0.002$ $\pm 0.0001 \mathrm{~g} / \mathrm{kg}$ ) than $\mathrm{AC} 8$. However, all the remaining strains including $\mathrm{AC} 1, \mathrm{AC} 2, \mathrm{AC} 3, \mathrm{AC} 4$ and $\mathrm{AC} 7$ induced with the same numeric values of $0.001 \pm 0.0001 \mathrm{~g} / \mathrm{kg}$ (Figure 2A).

Barley showed maximum association with AC8 which induced maximum amount of $0.81 \pm 0.04 \mathrm{~g} / \mathrm{kg}$ and stood first in terpenoids index. $\mathrm{AC} 1$ and $\mathrm{AC} 3$ were found second in terpenoids index with the numerical values of $0.54 \pm 0.03 \mathrm{~g} / \mathrm{kg}$. AC4 stood third and induced relatively lesser quantities of terpenoids $(0.36 \pm 0.02 \mathrm{~g} / \mathrm{kg})$ than $\mathrm{AC} 1$, $\mathrm{AC} 3$ and AC8. AC2 was next in terpenoids index with $0.27 \pm 0.01 \mathrm{~g} / \mathrm{kg}$. AC5 and AC7 were found with the numeric values of $0.18 \pm 0.01 \mathrm{~g} / \mathrm{kg}$ among eight microbial strains. Thus, AC6 was reported with least (0.09 $\pm 0.005 \mathrm{~g} / \mathrm{kg}$ ) terpenoid contents. Hence, barley had the maximum compatibility with AC8 as a best inducer to enhance terpenoid quantities among other selected microbial strains (Figure 2F). Mean $+\mathrm{SD}$ computed for quantitative variables. To compare the means of quantitative values one way ANOVA and DMRT test was applied. The $p$ value $(p \leq 0.05)$ was considered as statistically significant.

\section{Nutritional analysis after bacterial inoculum}

Results revealed that among eight tested microbial strains, AC8 showed maximum potential to induce vitamins including ascorbic acid, panthothenic acid, pyridoxine, thiamine and riboflavin (Figure 3). AC8 treated plants recorded with highest amounts of ascorbic acid $(0.032 \pm 0.001 \mathrm{~g} / \mathrm{kg})$. Following this AC3 and AC6 reported relatively lower amounts of ascorbic acid $(0.029 \pm 0.001$ and $0.027 \pm 0.001 \mathrm{~g} / \mathrm{kg}$ respectively). AC4 induced $0.023 \pm 0.001 \mathrm{~g} / \mathrm{kg}$ of ascorbic acid. AC2 induced less amount of ascorbic acid $(0.012 \pm 0.0007 \mathrm{~g} / \mathrm{kg})$ than AC4. $\mathrm{AC} 1$ and $\mathrm{AC} 5$ reported statistically $(\mathrm{p} \leq 0.05)$ almost equal quantities of ascorbic acid $(0.009 \pm 0.0005$ and $0.008 \pm 0.0004 \mathrm{~g} / \mathrm{kg})$. The least amount of ascorbic acid $(0.0013 \pm 0.00001$

\section{$\mathrm{g} / \mathrm{kg}$ ) was induced by AC7 (Figure 3A).}

AC6 stood first in niacin induction with $0.04 \pm 0.002 \mathrm{~g} / \mathrm{kg}$ among other microbial strains. AC8 occupied second position in niacin index $(0.028 \pm 0.001 \mathrm{~g} / \mathrm{kg})$. Whereas, AC3 and AC2 induced slightly lower values $(0.024 \pm 0.001 \mathrm{~g} / \mathrm{kg}$ and $0.023 \pm 0.001 \mathrm{~g} / \mathrm{kg})$ than AC8 (Figure 3B). AC1 treated plants possessed $0.012 \pm 0.001 \mathrm{~g} / \mathrm{kg}$ of niacin contents. Descending trend of niacin quantities in other microbial strains was found as, AC7 $>$ AC4 $>$ AC5 with numerical values of 0.0061 $\pm 0.0003>0.009 \pm 0.0005>0.002 \pm 0.0001 \mathrm{~g} / \mathrm{kg}$ respectively.

AC8 induced maximum amounts of panthothenic acid $(0.09 \pm$ $0.005 \mathrm{~g} / \mathrm{kg}$ ) among tested microbial strains, while AC3 and AC2 stood second in the panthothenic acid index with almost equal statistical ( $\mathrm{p}$ $\leq 0.05)$ values of $0.018 \pm 0.001 \mathrm{~g} / \mathrm{kg}$ and $0.016 \pm 0.0009 \mathrm{~g} / \mathrm{kg}$. Other microbial strains induced panthothenic acid as AC6 $(0.011 \pm 0.0006 \mathrm{~g} /$ $\mathrm{kg})>\operatorname{AC} 5(0.009 \pm 0.0005 \mathrm{~g} / \mathrm{kg})>\mathrm{AC} 1(0.009 \pm 0.0005 \mathrm{~g} / \mathrm{kg})>\mathrm{AC} 7(0.008$ $\pm 0.0004 \mathrm{~g} / \mathrm{kg})$. Least quantity of panthothenic acid $(0.002 \pm 0.0001 \mathrm{~g} /$ $\mathrm{kg}$ ) was induced by AC4 (Figure 3C).

AC6 induced maximum amounts of pyridoxine $(0.009 \pm 0.0005$ $\mathrm{g} / \mathrm{kg}$ ). AC5 occupied second position with production of pyridoxine $(0.003 \pm 0.0001 \mathrm{~g} / \mathrm{kg}) . \mathrm{AC} 3, \mathrm{AC} 8$ and $\mathrm{AC} 1$ induced relatively lower quantities of pyridoxine than AC5 but with insignificant difference among their values i.e., $0.0021 \pm 0.0001 \mathrm{~g} / \mathrm{kg}, 0.0019 \pm 0.0001 \mathrm{~g} / \mathrm{kg}$ and $0.002 \pm 0.0001 \mathrm{~g} / \mathrm{kg}$ respectively. AC2 $0.011 \pm 0.00001$, AC4 $0.001 \pm$ 0.00001 and AC7 $0.0009 \pm 0.00001 \mathrm{~g} / \mathrm{kg}$ induced least quantities of pyridoxine with insignificant difference among them (Figure 3D).

In case of thiamine, AC8 induced maximum amounts $(0.009 \pm$ $0.0005 \mathrm{~g} / \mathrm{kg}$ ) than other tested microbial strains. AC3 treated plants followed this with $0.008 \pm 0.0004 \mathrm{~g} / \mathrm{kg}$, which was significantly $(\mathrm{p} \leq$ $0.05)$ higher than $\mathrm{AC} 2$ and $\mathrm{AC} 7$ with equal numeric values $(0.006 \pm$ $0.0003 \mathrm{~g} / \mathrm{kg})$. AC6 induced even lesser quantity of thiamine $(0.003 \pm$ $0.0001 \mathrm{~g} / \mathrm{kg}$ ). AC1 recorded $0.002 \pm 0.0001 \mathrm{~g} / \mathrm{kg}$ of thiamine quantity. $\mathrm{AC} 4$ and $\mathrm{AC} 5$ were found responsible in equal induction of thiamine with $0.001 \pm 0.00001 \mathrm{~g} / \mathrm{kg}$ (Figure 3E).

AC3 induced highest contents of folic acid $(0.009 \pm 0.0005 \mathrm{~g} / \mathrm{kg})$ followed by AC1 and AC8 with the same values of $0.007 \pm 0.0004 \mathrm{~g} /$ $\mathrm{kg}$. AC6 ranked afterwards with $0.006 \pm 0.0003 \mathrm{~g} / \mathrm{kg}$ of folic acid. AC2, AC5, AC7 and AC4 induced almost equal amounts of folic acid $0.001 \pm$ $0.0001 \mathrm{~g} / \mathrm{kg}$ and $0.0009 \pm 0.0001 \mathrm{~g} / \mathrm{kg}$ respectively (Figure 3F).

Maximum amounts of riboflavin was induced by AC8 $(0.022 \pm$ $0.001 \mathrm{~g} / \mathrm{kg})$ with statistically $(\mathrm{p} \leq 0.05)$ significant from AC3 $(0.021 \pm$ $0.001 \mathrm{~g} / \mathrm{kg})$. AC2 occupied second position $(0.019 \pm 0.001 \mathrm{~g} / \mathrm{kg})$ and AC6 $(0.016 \pm 0.0009 \mathrm{~g} / \mathrm{kg})$ was reported at third place with significant difference than AC2. AC7 and AC4 induced riboflavin in equal quantities $(0.012 \pm 0.0007 \mathrm{~g} / \mathrm{kg})$. AC5 $(0.006 \pm 0.0003 \mathrm{~g} / \mathrm{kg})$ recorded relatively lower riboflavin quantity than AC4 and AC7 (Figure $3 \mathrm{G}$ ). The least amount of riboflavin was induced by $\mathrm{AC} 1$ with numeric value of $0.003 \pm 0.0001 \mathrm{~g} / \mathrm{kg}$.

AC8 induced maximum vitamin contents in barley than other microbial strains. AC3, AC6 scored secondary position among other tested strains as $\mathrm{AC} 2>\mathrm{AC} 7>\mathrm{AC} 4>\mathrm{AC} 5$ and $\mathrm{AC} 1$. Mean $+\mathrm{SD}$ computed for quantitative variables. To compare the means of quantitative values one way ANOVA and DMRT test was applied. The $\mathrm{p}$ value $(\mathrm{p} \leq 0.05)$ was considered as statistically significant.

\section{OSCs}

OSC reported mainly five isozymes in barley. OSCs also reported significant difference in $\mathrm{Rf}$ values on native page gel i.e., $\mathrm{OSC} 1=0.15$, OSC $2=0.352$, OSC $3=0.447$, OSC $4=0.562$ and OSC $5=0.737$ respectively (Figure 4). Microbial strains AC8 and AC3 induced maximum number of OSCs. Plants treated with these both strains revealed equal number and same species of OSCs isozymes. OSC1 was observed in all the eight microbial strains. Whereas, three OSCs species i.e., OSC2, OSC3 and OSC5 were exhibited same isozyme pattern in plants treated with microbial stains AC1, AC4, AC5 and AC6. OSC4 band was observed in AC1, AC3, AC4, AC5, AC6 and AC8 and was absent in AC3 and AC7. Two OSCs isozyme species OSC1 and OSC4 were observed in AC2 and AC7 treated plants (Figure 4). The pattern between plants treated with $\mathrm{AC} 2$ and $\mathrm{AC} 7$ had $50 \%$ resemblance due to the presence of OSC 3 band in them. Likewise, AC8 treated plants exhibited 50\% similarity to AC2 and $\mathrm{AC} 7$ due to the presence of OSC3 isozyme band in them. 

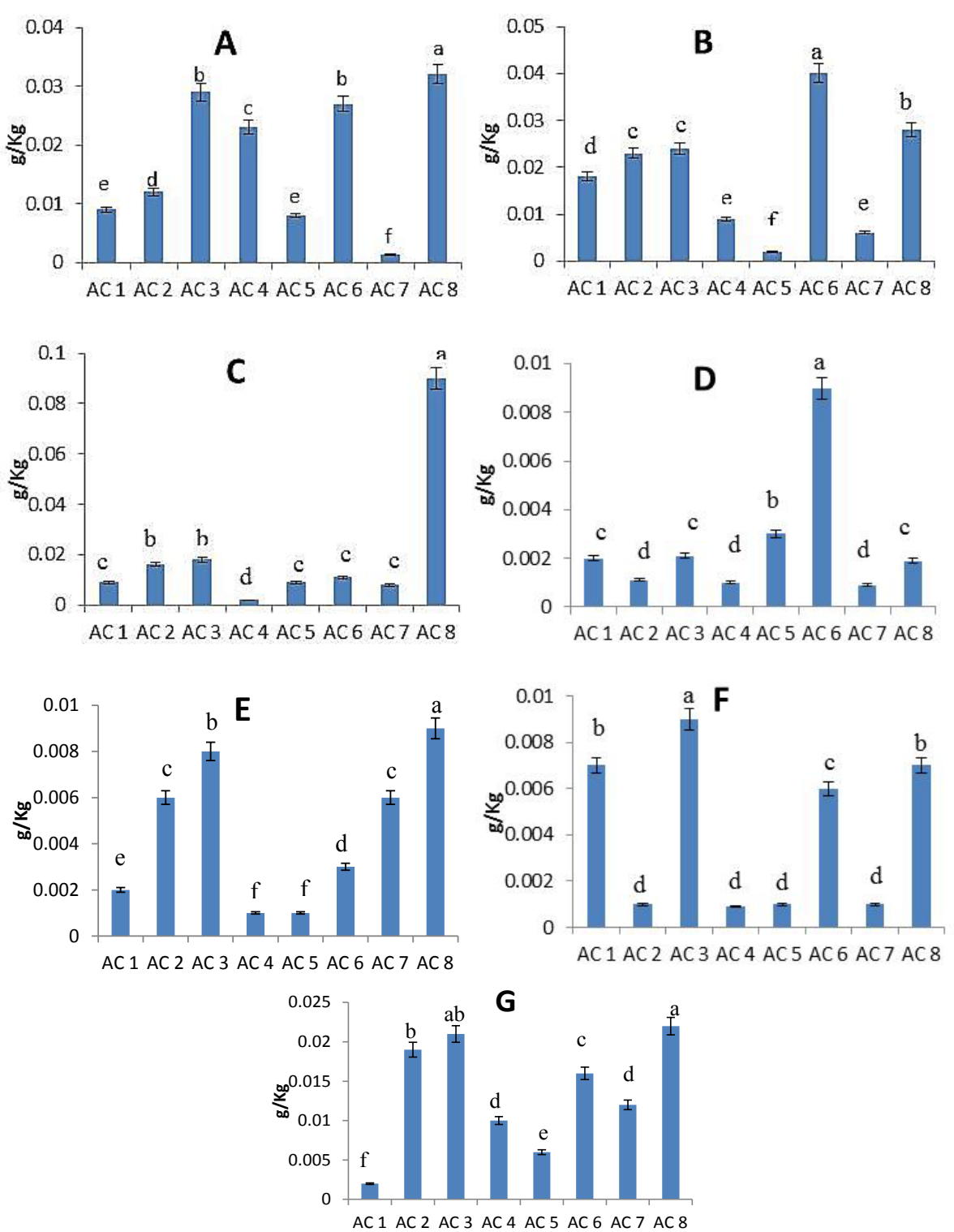

Figure 3: Quantification of vitamins i.e., Ascorbic Acid (A), Niacin (B), Pantothenic acid (C), Pyridoxine (D), Thiamine (E), Folic acid (F), Riboflavin (G) in barley after different microbial strain applications (ACE1, ACE2, ACE3..... ACE8). Data were statistically analyzed through DMRT at $p \leq 0.05$ and significance of results has been mentioned through alphabets, while standard error has been plotted by error bars.

However, AC1 and AC8 exposed plants showed two OSCs isozyme species i.e., OSC3 and OSC5 in their isozyme profile. AC1 and AC8 did not share any band with the AC2 and AC7 isozyme profiles, but all of their bands were present in rest of the five microbial strains treatments i.e., $\mathrm{AC} 1, \mathrm{AC} 3, \mathrm{AC} 4, \mathrm{AC} 5$ and AC6.

OSC2 band was recorded with $8.7 \%$ increased intensity than OSC5 band in AC8 (Figure 5A). In case of OSC3 isozyme the maximum intensity was recorded in AC2 and AC7 while OSC4 recorded in the least intensity (Figure 5B). Whereas, OSC2 recorded with $20 \%$ increased intensity in AC7 and AC8 than AC5 and AC6. Similarly OSC4 and OSC5 reported with $9 \%$ increased intensity with $12.5 \%$ in $\mathrm{AC} 1$ and $\mathrm{AC} 3$ than $\mathrm{AC} 5$ (Figure 5B and 5C). OSC1 and OSC4 isozyme species recorded with $5 \%$ decreased intensity in $\mathrm{AC} 2$ and $\mathrm{AC} 7$ than AC8 (Figure 5D and 5E). In case of AC7 and AC8 treatments, OSC3 recorded with $9 \%$ increased intensity than OSC4. While, OSC3 showed maximum intensity in $\mathrm{AC7}$ and $\mathrm{AC} 8$ respectively (Figure $5 \mathrm{~F}$ and $5 \mathrm{G}$ ). Other isozymes recorded decreased intensities in descending order as $\mathrm{OSC} 1>\mathrm{OSC} 2>\mathrm{OSC} 5$. But the same pattern was found in AC3 and AC8 profiles. All the bands recorded in AC8 treated plants had slightly higher intensities than AC3.

\section{Discussion and Conclusion}

Acetobacter aceti is a naturally occurring gram negative microorganism, present everywhere in the environment. It is widely distributed in water and soil [33]. They are obligate aerobic microorganism and grow best at temperature between 25 to $30^{\circ} \mathrm{C}$. This microorganism had a strong history in modulation of foods. They have been used in fermentation industry for a long time to produce 


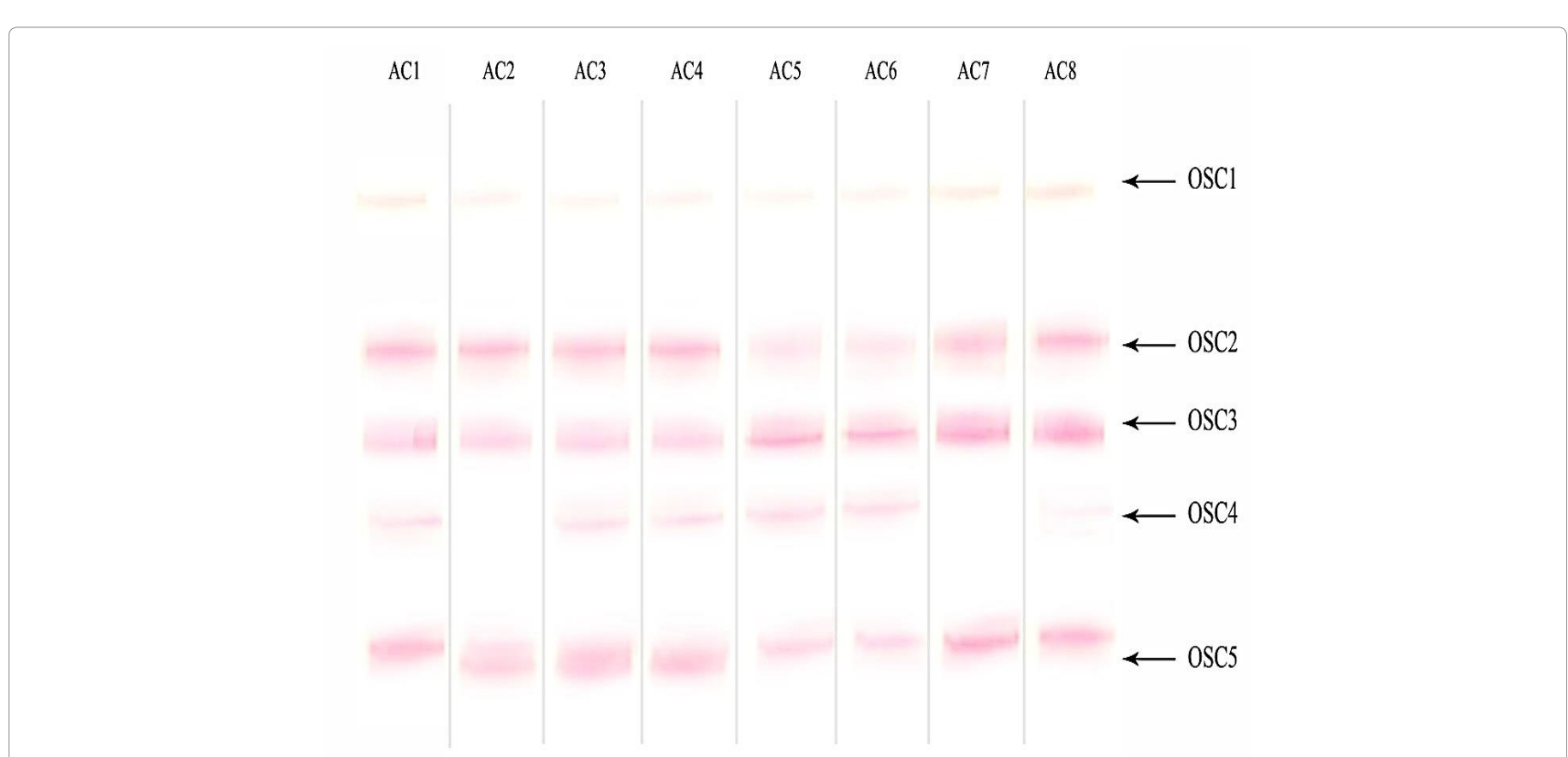

Figure 4: Native PAGE gel image of isozyme analysis of Oxidosqualene Cyclase (OSC) in eight microbial strains i.e., AC1, AC2, AC3..... AC8. Isozymes having significantly different Rf values have been titled with codes i.e., OSC1, OSC2.... OSC5.

acetic acid from alcohol [34]. They have been used in food industry since 1850's for the vinegar and wine production [35]. According to [36] A. aceti is safe to handle in food and beverage industry and do not cause any pathogenicity to humans. A study by Ref. [37] showed that this microbe has been used for cellulose production in paper and headphone industry as well for a long time.

PGPR has a great association with plants because they are present in plant roots under the upper layer of soil. They give support in plant production. The situation is much clearer with mycorrhizal bacteria where, through ecologically mutualistic symbiosis with the plant, the major feature involves improving plant nutritional status, perhaps water balance and thus plant growth [38]. During this study eight strains of bacillus have been procured from soil of agricultural department and used against staple food crops as inducer. Later on, after experimentation acetobacter aceti was identified as the best strain that have maximum affinity with the selected staple food crops.

The present study highlighted that microbial treatments affect physiological metabolism inside the plant body. Similar facts were explained by earlier workers [39-41]. Commonly, they can change the rates where genes are being transcribed inside the plant cells. Transcriptional rates modify nutritional contents of foods, thus modulating nutritional composition of plant produce [42-44]. Therefore, composition of plant produce can be modified by application of specific microbial treatments. In this way, food quality and yield can be improved through directing transcriptional modification of genes in a specific direction [45]. Current study describes the modulation of transcriptional rates of SS genes in order to improve phytosterol contents of barley. Thus, the investigation strengthens all previous reported studies in this direction and concluded that microbial isolates may be potentially used to improve phytosterol contents in routine diet [46-48].

Most effective inducer bacillus microbial species was identified as A. aceti (FCBP-537). A. aceti has never been involved in economically important plant and human disease. Therefore, it would be safe to use in agricultural fields to elevate the transcription of SS genes and nutritional contents in desired staple food crops [49]. Therefore, in this study active metabolites from $A$. aceti were studied and identified, which were responsible for enhancement of transcriptional rate of SS genes and nutritional profile in barley [50].

Transcriptional processes going on inside the plant cells are very complex in nature [51]. Therefore, the quantification of actual phytosterol contents was performed and it was recorded that highest quantities of phytosterols were present in seeds of $A$. aceti treated plants. It is important because $A$. aceti also recorded the maximum induction of SS genes during transcriptional analysis. Moreover, strain AC7 showed the least induction of SS genes, and it also recorded the least quantities of phytosterols in barley seeds. Hence, the current study proved a strict association between SS gene transcriptional rates and actual phytosterol contents. This finding comes in agreement with Ref. [52].

Further investigations described relationship between staple food crops and microbial strains, and how they elevate different plant biochemicals and other nutrients [53]. Procuring maximum nutrients from daily food is always an interesting phenomenon for the researchers and scientists [54]. There are many researchers discovering the effects of biological applications on plant metabolism [55-58]. Such microbial applications modulate plant metabolic pathways, hence may change the whole biochemical profile of plants $[58,59]$. Current investigation evaluates the efficacy of different microbial species for their potential to induce nutritional contents in plant produce. It would be a safer and cheaper way to get higher nutrition from normal food crops.

Bacterial strain AC6 could only induce two nutritional elements i.e. Niacin and Pyridoxine significantly higher than all other microbial applications. However, only one nutritional factor (Folic acid) was efficiently induced by AC3 application. Four nutritional contents i.e. pantothenic acid; thiamine, riboflavin and ascorbic acid out of 

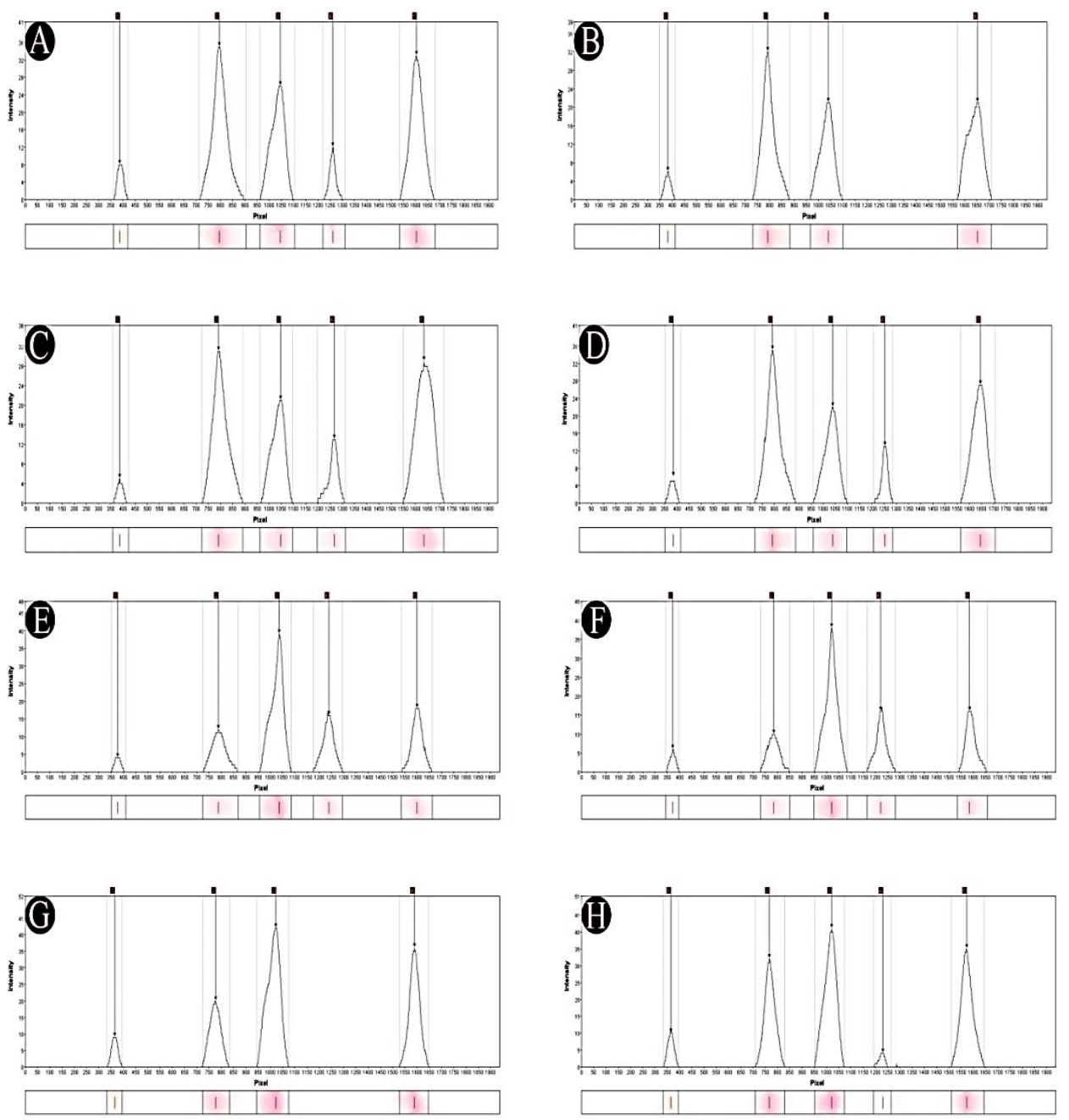

Figure 5: Band intensity based analysis of 'Figure 3' showing precise position of each band with numeric values of their intensities. Analysis of eight microbial strains (i.e., AC1: A; AC2: B; AC3: C; AC4: D; AC5: E; AC6: F; AC7: G; and AC8: H) was carried out by using GELANALYZER (Lazar, Hungary). Gel slices have been provided under intensity based graphs of each sample and shows the position of sample run on 'Native PAGE' gel.

seven nutritional elements were induced most efficiently by AC8. The identification of this inducer species was carried out as $A$. aceti (FCBP 537). The particular microbial species has been reported as nonpathogenic to plants as well as humans, therefore is recommended to be applied in agriculture farms without any risk [60].

It was recorded during present study that AC6 was the second best microbial application in terms of phytosterols induction, and phytosterols are very important food component specifically with reference to circulatory disorders [61]. Therefore, pectins are responsible for plant signaling pathways and play their role in seed coat hardening and define food shelf life [62]. Moreover, it decreases the cholesterol absorbance from other foods, thus foods with higher pectin contents are recommended for hyperlipidemia patients $[63,64]$. Therefore, microbial application of strain AC8 induced maximum pectin contents in barley and this is recommended to use in diet to prevent hyperlipidemia. Furthermore, the same microbial species AC6 was involved in the elevation of alkaloids in barley seeds, which is a very important defense chemical. However, its elevated quantities have strong inverse relation with food palatability [65]. The large alkaloid contents are toxic to humans as well as animals, and are strictly prohibited to be consumed in the form of food [66]. Even, their higher quantities cannot be used in medicines [67]. Toxicity of saponins towards humans and mammals and their inverse relation with food palatability are also documented by Ref.'s $[68,69]$. Therefore, the application of microbial species AC4 responsible for maximum induction of saponins can never be encouraged. However, AC8 was among the microbial applications showing moderate increase in saponin induction. Therefore, application of AC8 would be the best option according to this aspect.

It was recorded that three microbial applications i.e., AC1, AC6 and AC8 significantly elevated phenolics content in barley, which is an indication of stronger defense against a vast range of pathogens [70]. Moreover, phenolics exhibit anti-properties and play important role in therapeutic processes and healing of wounds [70]. Thus, human foods must contain sufficient amount of phenolics to provide curative and medicinal effects. Similarly, tannins are important biochemical restricting microbe linkages to host surface [71] growth and disorders of pathogenic cell [72] including abnormal function of pathogenic 
Citation: Yousaf A, Qadir A, Anjum T, Khan RI, Naughton D, et al. (2017) Evaluation of Bacterial Strains for the Induction of Plant Biochemicals, Nutritional Contents and Isozymes in Barley. J Nutr Food Sci 7: 623. doi: 10.4172/2155-9600.1000623

Page 10 of 12

protein [73]. A number of studies in the past have concluded that those foods which have higher tannin contents have more potential to deal with health benefits [74]. According to current investigation, microbial application of AC8 was again found as the best option for elevation of tannin contents in barley seeds.

Terpenoids is important biochemical with respect to indirect insect resistance due to their significant attraction towards insect predators $[75,76]$. They also protect plants from insect transmitted viral diseases [77]. Therefore the application of AC8 can also be encouraged to avoid insect attacks and related viral diseases. Coumarins are considered as important antifungal defense of plants which enhance food palatability due to their pleasant odor $[78,79]$. Their anticoagulant properties are also well-known to researchers due to which they are also a recommended food component $[80,81]$. Currently, AC2, AC3 and AC8 were found as the leading microbial applications in the hierarchy of coumarins induction. Therefore, any of the three microbial species can be utilized to enhance palatability of barley. AC8 was important with reference to induction of phytosterol contents in barley, which are inversely associated with regulating cholesterol absorption in human body [82] Increased quantities of phytosterols enhance the lipid metabolism and lower total cholesterol with reduction in blood pressure [83]. Keeping in mind all these results application of AC8 microbial strain gained much importance because it induced maximum phytosterols along other plant biochemicals. Vitamins belong to a cohesive group of biochemicals which are required in very minute quantities in human body to perform better function. Their major role is in absorbance of minerals, assimilation of nutrients, regulation of metabolism and synthesis of proteins [84]. Therefore, procurement of healthy quantities of vitamins has always been a point of interest. Current investigation showed that bacterial applications affect the vitamin contents of barley seeds, and AC8 also proved as the best microbial strain in terms of vitamin elevation. Moreover, the consumption of AC8 treated barley seeds would be beneficial for the persons who want to lose their weight without the risk of vitamin deficiency syndrome.

Oxidosqualene Cylases (OC) are responsible for the utilization of squalene in the production of phytosterols. However, it is a general notation that higher quantities of oxidosqualene cyclases lead toward increased quantities of phytosterols [85]. The same phenomenon was observed in current investigation when microbial applications increased phytosterol contents with enhanced activity of oxidosqualene cyclases. Therefore, it can be concluded that the microbial application may change the transcriptional profile of plant cell both quantitatively as well as qualitatively.

Phytosterols are synthesized by utilizing squalene substrate, which is regulated by oxidosqualene cyclase. Oxidosqualene cyclase is responsible for keeping balance among phytosterols, terpenoids and saponins $[86,87]$. Current investigation recorded that AC8 induced the quantities of phytosterols and decreased the saponin contents. It concluded that AC8 directed the metabolism towards phytosterols production. On the other hand AC4 modulated barley metabolism towards production of saponins, and that elevation of saponin contents resulted into reduced quantities of phytosterols and triterpenes. Therefore, AC4 was not recommended for barley production. However, AC8 elevated the phytosterols and decreased saponins putting a two way beneficial effect on food quality of barley; therefore highly recommended to augment nutritional value of barley seeds.

Due to plant microbe interaction elevated levels of proteins were also observed in barley. AC8 microbial strain helped the overall metabolic processes in barley. Earlier workers [88-90] had concluded in their previous studies that increased plants resistance is directly proportional to the elevated levels of proteins in their proteomic profiles. Because all the inner and intracellular interactions are due to the presence of proteins [91]. Increased quantities of proteins or elevated gene expression put more intracellular pressure to perform their metabolic functions more efficiently. That way more or less nutrients are absorbed by plants. Thus, the basic plant nutrients also help to give them resistance. Enhanced protein levels also give resistance to plants either naturally or can be boost up their function with the aid of microbes.

The current investigation described an array of metabolites which affect plant biochemicals. This study has highlighted the metabolites which more specifically enhanced nutritional quality related biochemicals in barley seeds. Barley is a staple food crop which can be routinely consumed by humans and animals. Therefore, the current investigation was advancement in the improvement of food quality of large population. It recommended the plant microbe applications for gaining elevated levels of plant produce and nutritionally important vitamins.

\section{References}

1. Barthelemy D, Caraglio $Y$ (2007) Plant architecture. A dynamic, multilevel and comprehensive approach to plant form, structure and ontogeny. Ann Bot 99 : 375-407.

2. Paungfoo-Lonhienne C, Rentsch D, Robatzek S, Webb RI, Sagulenko E, et al (2010a) Turning the table: Plants consume microbes as a source of nutrients. PLoS One 5: E11915.

3. Paungfoo-Lonhienne C, Schmidt S, Lonhienne TG (2010b) Uptake of nonpathogenic E. coli by Arabidopsis induces down regulation of heat shock proteins. Plant Signal Behav 5.

4. Bashan $Y$ (1998) Azospirillum plant growth promoting strains are nonpathogenic on tomato, pepper, cotton and wheat. Canadian Journal of Microbiology 44: 168-174.

5. Shishido M, Chanway CP (1998) Spruce growth response specificity after treatment with plant growth promoting pseudomonads. Canadian Journal of Botany 77: 22-31.

6. John M, Whipps L (2001) Microbial interactions and biocontrol in the rhizosphere. J Exp Bot 52: 487-511.

7. Whitelaw MA (2000) Growth promotion of plants inoculated with phosphatesolubilizing fungi. Advances in Agronomy 69: 99-151.

8. Hong Y, Pasternak JJ, Glick BR (1991) Biological consequences of plasmid transformation of the plant growth promoting rhizobacterium Pseudomonas putida GR12-2. Canadian Journal of Microbiology 37: 796-799.

9. Glick BR (1995) The enhancement of plant growth by free-living bacteria Canadian Journal of Microbiology 41: 109-117.

10. Garbaye J (1994) Helper bacteria: a new dimension to the mycorrhizal symbiosis. New Phytologist 128: 197-210.

11. Arshad M, Frankenberger Jr WT (1991). Microbial production of plant hormones. In: Keister DL, Cregan PB (eds.) The rhizosphere and plant growth. Dordrecht. The Netherlands. Kluwer Academic Publishers pp: 327-334.

12. Beyeler M, Keel C, Michaux P, Haas D (1999) Enhanced production of indole3-acetic acid by a genetically modified strain of Pseudomonas fluorescens $\mathrm{CHAO}$ affects root growth of cucumber, but does not improve protection of the plant against Pythium root rot. FEMS Microbiology Ecology 28: 225-233.

13. Burd GI, Dixon DG, Glick BR (1998) A plant growth-promoting bacterium that decreases nickel toxicity in seedlings. Appl Environ Microbiol 64: 3663-3668.

14. Nehl DB, Allen SJ, Brown JF (1996) Deleterious rhizosphere bacteria: an integrating perspective. Applied Soil Ecology 5: 1-20.

15. Vesper SJ (1987) Production of pili fimbriae by Pseudomonas fluorescens and a correlation with attachment to corn roots Appl Environ Microbiol 53 1397-1405.

16. Maynard AJ (1970) Methods in food analysis. Academic Press, NY, USA, p: 176. 
Citation: Yousaf A, Qadir A, Anjum T, Khan RI, Naughton D, et al. (2017) Evaluation of Bacterial Strains for the Induction of Plant Biochemicals, Nutritional Contents and Isozymes in Barley. J Nutr Food Sci 7: 623. doi: 10.4172/2155-9600.1000623

17. Abbas C, Anne RM, Beery K (2003) Preferential extraction of sterols and fatty acids using mixtures of ethanol and water efficiency. United States Patent Application Publication

18. Osório AC, Martins JLS (2004) Determinação de cumarina em extrato fluido e tintura de guaco por espectrofotometria derivada de primeira ordem. Brazilian Journal of Pharmaceutical Sciences 40: 481-486.

19. Van-Burden, Robinton TP (1981) Formation of complexes between protein and tannin acid. Journal of Agriculture and Food Chemistry 1: 77-82

20. Boham AB, Kocipai AC (1994) Flavonoid and condensed tannins from leaves of Hawaiian Vaccininum and Vicalycinium Vaticulum. Pacific Science 48: 458-463.

21. Daise Lopes-Lutz, Dettmann J, Nimalaratne C, Schieber A (2010) Characterization and quantification of polyphenols in amazon grape (Pourouma cecropiifolia Martius). Molecules 15: 8543-8552.

22. Obadoni K, Lisa K, Carell GH, Stefen K (2001) Significance of saponins and alkaloids in induced indirect plant defense against herbivorous arthropods. Plant Cell Environment 46: 375-385

23. Horwitz W, Peter J, Jospeh K (2000) Official methods of analytical chemistry of AOAC International, $17^{\text {th }}$ edition, AOAC International suite 500,481 Nork Frederick Avenue Gaithers Burg, Maryland. USA.

24. Eroglu E, Melis A (2010) Extracellular terpenoid hydrocarbon extraction and quantitation from the green microalgae Botryococcus Braunii Var. Showa. Bioresource Technology 101: 2359-2366.

25. Okwu DE, Josiah C, Kramer N, Njoku A (2006) Evaluation of the chemica composition of two Nigerian medicinal plants. African Journal of Biotechnology 5: $357-361$.

26. Saeed A, Najma S, Farhan AS, Hashim Z, Zeeshan M (2007)Spectrophotometric methods for the simultaneous analysis of meclizine hydrochloride and pyridoxine hydrochloride in bulk drug and pharmaceutical formulations. Pakistan Journal of Pharmaceutical Science 20: 149-156.

27. Hudson TS, Subramanian S, Allen RJ (1984) Determination of pantothenic acid, biotin and vitamin B12 in nutritional products. Journal of Analytical Chemistry 67: 994-998.

28. Alaa FH, Muneer AAL, Abd-almutalb BMA (2010) Spectrophotometric determination of thiamine. HCL in pharmaceutical preparations using Prussian blue reaction. Journal of Kerbala University 8: 219-226.

29. Matias M, Ribeiro PRS, Sarraguca MC, Lopes JA (2014) A UV spectrophotometric method for the determination of folic acid in pharmaceutical tablets and dissolution tests. Journal of Analytical Methods 6: 3065-3071.

30. Hussian I, Saleem M, Iqbal Y, Khalil SJ (2006) Comparison of Vitamin C Contents in Commercial Tea Brands and Fresh Tea Leaves. Journal of Chemical Society Pakistan 28: 421-425.

31. Ruth FI, Gill DM (1964). A microbiuret method for estimating proteins. Analytical Biochemistry 9: 401-410.

32. Parvin R, Pande SV, Venkitasubramanian TA (1965). On the colorimetric biuret method of protein determination. Analytical Biochemistry 12: 219-229.

33. United States Environmental Protection Agency (2012). Acetobacter aceti final risk assessment. Biotechnology Program under Toxic Substances Control Act (TSCA) USEPA.

34. Kiyoshi T, Tomoko A (1994) Acetic acid production by Acetobacter aceti in a silicon tube bioreactor. Biotechnology Letters 16: 617-620.

35. Lafon-Lafourcade S (1983) Wine and brandy. In Biotechnology 5: 81-163.

36. Watanabe M, Lino S (1984). Studies on bacteria isolated from Japanese wines. Part 2 Growth of the Acetobacter spp. A-1 during the fermentation and the storage of grape must and red wine. Yamanshiken Shokukin Kogyo Shidojo Kenkyu Hokoku 16: 13-22.

37. Anonymous (1989) Food product development. From concept to the market place. The Fortune p: 345.

38. Hooker JE, Jaizme-Vega M, Atkinson D (1994) Biocontrol of plant pathogens using arbuscular mycorrhizal fungi. In: Gianinazzi S, Schüepp H (eds.) Impact of arbuscular mycorrhizas on sustainable agriculture and natural ecosystems. Basel, Switzerland: Birkhäuser Verlag, pp: 191-200.

39. Schallau K, Junker BH (2010) Simulating plant metabolic pathways with enzyme-kinetic models. Plant Physiol 152: 1763-1771.
40. Ahemad M, Kibret M (2014) Mechanisms and applications of plant growth promoting rhizobacteria: current perspective. Journal of King Saudia University and Science 26: 1-20.

41. Lau W, Fischbach MA, Osbourn A, Sattely ES (2014) Key applications of plan metabolic engineering. PLoS Biology 12: e1001879.

42. Georgieva I, Edreva A, Rodeva R, Sotirova V, Stoimenova E (2000) Metabolic changes in tomato fruits and seeds after viral, microbial and fungal infections. Acta Physiology Plant 22: 281-284.

43. Duan G, Christian N, Schwachtje J,Walther D, Ebenhöh O (2013) The metabolic inter play between plants and phytopathogens Metabolites 3: 1-23.

44. Ruzanski C, Smirnova J, Rejzek M, Cockburn D, Pedersen HL, Pike M (2013) A microbial glucanotransferase can replace the complex barleyose metabolism required for starch to sucrose conversion in leaves at night. Journal of Biology and Chemistry 288: 28581-28598.

45. Gabriele B (2009) Plant microbe interactions promoting plant growth and health. Perspectives for controlled use of microorganisms in agriculture Applied Microbiology and Biotechnology 84: 11-18.

46. Smith KP, Handelsman J, Godman RM (1999) Genetic basis in plants for interactions with disease suppressive bacteria. Production of Natural Academy of Science USA 9: 4786-4790.

47. Lugtenberg BJJ, Chin-A-Woeng TFC, Bloemberg GV (2002). Microbe plant interactions, principles and mechanisms. Antonie Van Leeuwenhoek 81: 373-383.

48. Morrissey JP, Dow JM, Mark L, O'Gara F (2004) Are microbes at the root of a solution to world food production? European Molecular Biology Organization EMBO Reports 5: 922-926.

49. Tapia-Hernandez A, Bustillos-Cristales MR, Jimenez-Salgado T, CaballeroMellado J, Fuentes-Ramirez LE (2000) Natural endophytic occurrence of "acetobacter diazotrophicus" in pineapple plants. Microbial Ecology 39: 49-55.

50. Anam Y, Abdul Q, Tehmina A, Aqeel A (2015) Identification of microbial metabolites elevating vitamin contents in barley seeds. Journal of Agricultural and Food Chemistry 63: 7304-7310.

51. De-Lay J, Gillis M, Swings J (1984). Family VI. Acetobacteraceae. Bergey's Manual of Systematic Bacteriology 1: 267-278.

52. Lee MH, Jeong JH, Seo JW, Shin CG, Kim YS, et al. (2004) Enhanced triterpene and phytosterol biosynthesis in Panax ginseng over expressing squalene synthase gene. Plant Cell Physiology 45: 976-984.

53. Opelt K, Berg C, Berg G (2007) The bryophyte genus 'sphagnum' is a reservoir for powerful and extraordinary antagonists and potentially facultative human pathogens. Fedration of European Microbiological Societies (FEMS). Microbiology Ecology 61: 38-53.

54. Zabetakis C (1997) Enhancement of havour biosynthesis from strawberry 'fragaria $x$ ananassa callus' cultures by methylobacterium species. Plant Cell Tissue Organ Culture 50: 179-183.

55. Zachow C, Berg C, Muller H, Meincke R, Komon ZM, et al. (2009) Funga diversity in the rhizosphere of endemic plant species of 'tenerife' canary Islands, relationship to vegetation zones and environmental factors. The Multidisciplinary Journal of Micribial Ecology (ISME) 3: 79-92.

56. Shafique S, Shafique S, Ahmed A (2013) Ecofriendly response of citrus peels to Alternaria leaf spots of tomato: Exclusive role of peel phenolics. International Journal of Agriculture and Biology 15: 1236-1242.

57. Akram W, Anjum T, Ali B, Ahmad A (2013) Screening of native Bacillus strains to induce systemic resistance in tomato plants against Fusarium wilt in split root system and its field applications. International Journal of Agriculture and Biology 15: 1289-1294.

58. Van-Loon LC (2007) Plant responses to plant growth promoting bacteria European Journal of Plant Pathology 119: 243-254.

59. Ahmad A, Shafique S, Shafique S, Akram W (2014) Penicillium oxalicum directed systemic resistance in tomato against Alternaria alternata. Acta Physiology Plant.

60. Ukwo SP, Ezeama CF (2011) Studies on proliferation of acetic acid bacteria during soursop juice fermentaion. International Journal of Food Safety 13: 345-350.

61. Nguyen $T$ (1999) The cholesterol lowering action of plant stanol esters. The Journal of Nutrition 129: 2109-2112. 
Citation: Yousaf A, Qadir A, Anjum T, Khan RI, Naughton D, et al. (2017) Evaluation of Bacterial Strains for the Induction of Plant Biochemicals, Nutritional Contents and Isozymes in Barley. J Nutr Food Sci 7: 623. doi: 10.4172/2155-9600.1000623

62. Vorwerk S, Somerville S, Somerville C (2004) The role of plant cell wall polysaccharide composition in disease resistance. Trends in Plant Science 9: 203-209

63. Nkunda DS, Mugisha J, Muzuri C (2011) A study on cooking times of fresh and aged beans (Phaseolus vulgaris) in selected aqueous solutions and their pectin methylesterase activities. KIST Journal of Science and Technology 1: 15-21.

64. Takeuchi W, Mitsunaga S-I, Masui H (2011) Studies on germination conditions of germinated brown rice to improve the palatability. Journal of Applied Glycoscides 58: 27-30.

65. Marten GC, Jordan RM, Hovin AW (1976) Biological significance of reed canarygrass alkaloids and associated palatability variation to grazing sheep and cattle. Agronomy Journal 68: 909-914.

66. Namita P, Mukesh R (2012) Medicinal plants used as anti-agents: A review. International Research Journal of Pharmacy 3: 31-40.

67. Roeder E (2000) Medicinal plants in China containing pyrrolizidine alkaloids. Pharmazie 55: 711-726.

68. Chugh CA, Mehta S, Heena DUA (2012) Phytochemical screening and evaluation of biological activities of some medicinal plants of phagwara, Punjab. Asian Journal of Chemistry 24: 5903-5905.

69. Kuljanabhagavad T, Thongphasuk P, Chmulitrat W, Wink M (2008) Triterpene saponins from Chenopodium quinoa Wild. Phytochem 69: 1919-1926.

70. Ahmad A, Shafique S, Shafique S (2013) Cytological and physiological basis for tomato varietal resistance against Alternaria alternata. J Sci Food Agric 93: 2315-2322.

71. Nwanyanwu CE, Alisi CS, Nweke CO, Orji JC (2012) Cell surface properties of phenol-utilizing bacteria isolated from petroleum refinery wastewater. Journal of Research in Biology 2: 383-391.

72. Aliyu AB, Musa AM, Abdullahi MS, Oyewale AO, Gwarzo US (2008) Activity of plant extracts used in northern nigerian traditional medicine against methicillinresistant Staphylococcus aureus (MRSA). Nigerian Journal of Pharmaceutical Sciences 7: 1-8.

73. Cowan MM (1999) Plant products as anti-agents. Clinical Microbiology Revision 12: $564-582$.

74. Chung KT, Wong TY, Wei Cl, Huang YW, Lin Y (1998) Tannins and human health, a review. Crit Rev Food Sci Nutr 38: 421-464.

75. Martin VJ, Pitera DJ, Withers ST, Newman JD, Keasling JD (2003) Engineering a mevalonate pathway in Escherichia coli for production of terpenoids. National Biotechnology 21: 796-802.

76. Miller B, Madilao LL, Ralph S, Bohlmann J (2005) Insect-induced conifer defense: white pine weevil and methyl jasmonate induce traumatic resinosis, de novo formed volatile emissions, and accumulation of terpenoid synthase and putative octadecanoid pathway transcripts in Sitka spruce. Plant Physiol. 137: 369-382.
77. Mumm R, Posthumus MA, Dicke M (2008) Significance of terpenoids in induced indirect plant defence against herbivorous arthropods. Plant Cell Environ 31: $575-585$.

78. De Araújo RSA, Guerra FQS, Lima EO, de Simone CA, Tavares JF, et al. (2013) Synthesis structure-activity relationships (SAR) and in Silico studies of coumarin derivatives with antifungal activity. International Journal of Molecular Sciences 14: 1293-1309.

79. Awohouedji DYG, Lesse P, Houinato M, Hounzangbe-Adote S (2013) Medicinal forage present in the natural pasture in Benin: Review article. Journal of Animal Production Advances 3: 301-310.

80. Hoult JRS, Miguel P (1996) Pharmacological and biochemical actions of simple coumarins, natural products with therapecutic potential general pharmacology. Gen Pharmacol 27: 713-722.

81. Lake BG (1999) Coumarin metabolism toxicity and carcinogenicity, relevance for human risk assessment. Food Chem Toxicol 37: 423-453.

82. Potter SM (2000) Soy-new health benefits associated with an ancient food. Nutrition Today 35: 53-60.

83. Hoffman JR, Falvo MJ (2004) Protein-which is best? Journal Sports Science Medicine 3: 118-130.

84. D'Ambrosio DN, Clugston RD, Blaner WS (2011) Vitamin A metabolism; an update. Nutrients 3: 63-103.

85. Kim TD, Han JY, Huh GH, Choi YE (2011) Expression and functional characterization of three squalene synthase genes associated with saponin biosynthesis in Panax ginseng. Plant Cell Physiology 52: 125-137.

86. Moses T, Pollier J, Almagro L, Buyst D, Montagu MV, et al. (2014) Combinatoria biosynthesis of sapogenins and saponins in Saccharomyces cerevisiae using a C-16a hydroxylase from Bupleurum falcatum PNAS.

87. Sioen I, Matthys C, Huybrechts I (2011) Consumption of plant sterols in Belgium: Estimated intakes and sources of naturally occurring plant sterols and beta carotene. Br J Nutr 105: 960-966.

88. Ellis JG, Dodds PN, Lawrence GJ (2007) Flax rust resistance gene specificity is based on direct resistance-avirulence protein interactions. Annual Review of Phytopathology 45: 289-306.

89. Fradin EF, Zhang Z, Ayala JCJ, Castroverde CDM, Nazar RN, et al. (2009) Genetic dissection of Verticillium wilt resistance mediated by tomato Ve1. Plant Physiol 150: 320-332.

90. Zhu H, Li GJ, Ding L, Cui X, Berg H, et al. (2009) Arabidopsis extra-large G-protein 2 (XLG2) interacts with the Gbeta subunit of heterotrimeric $G$ protein and functions in disease resistance. Molecular Plant 2: 513-525.

91. Bernstein AM (2010) Major dietary protein sources and risk of coronary heart disease in women. Circulation 122: 876-883.
Citation: Yousaf A, Qadir A, Anjum T, Khan RI, Naughton D, et al. (2017) Evaluation of Bacterial Strains for the Induction of Plant Biochemicals, Nutritional Contents and Isozymes in Barley. J Nutr Food Sci 7: 623. doi: 10.4172/2155-9600.1000623
OMICS International: Open Access Publication Benefits \& Features

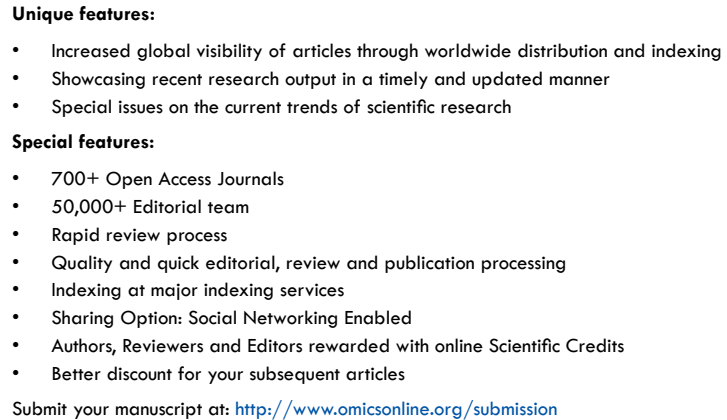

